Prepared in cooperation with DeKalb County, Georgia

\title{
Flood-Inundation Maps for South Fork Peachtree Creek From the Brockett Road Bridge to the Willivee Drive Bridge, DeKalb County, Georgia
}


Pamphlet to accompany

Scientific Investigations Map 3347
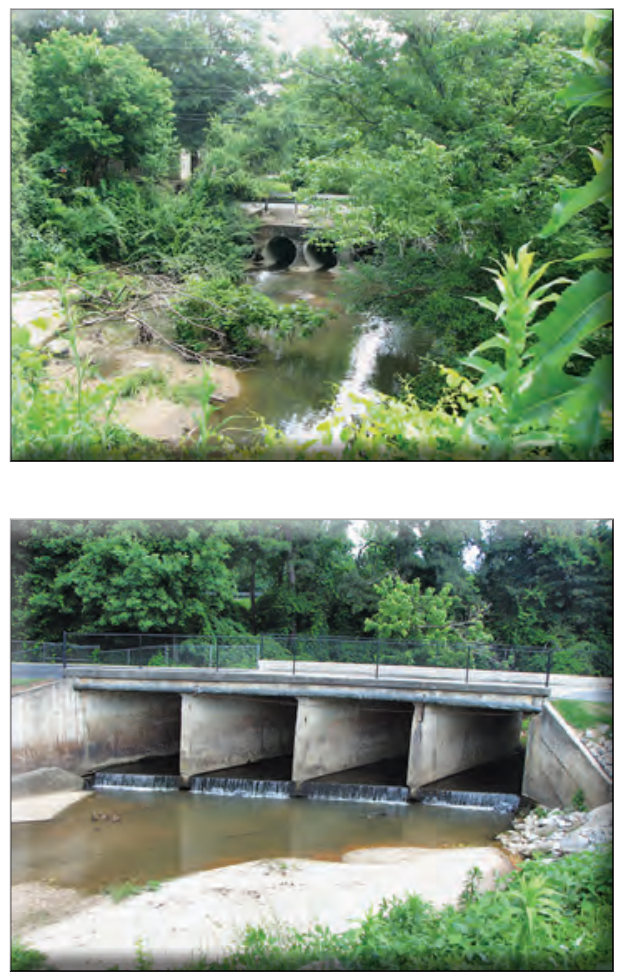

U.S. Department of the Interior

U.S. Geological Survey 
Cover. South Fork Peachtree Creek, DeKalb County, Georgia, in various settings. 


\section{Flood-Inundation Maps for South Fork Peachtree Creek From the Brockett Road Bridge to the Willivee Drive Bridge, DeKalb County, Georgia}

By Jonathan W. Musser

Prepared in cooperation with DeKalb County, Georgia

\section{Pamphlet to accompany}

Scientific Investigations Map 3347 


\title{
U.S. Department of the Interior SALLY JEWELL, Secretary
}

\section{U.S. Geological Survey \\ Suzette M. Kimball, Acting Director}

\author{
U.S. Geological Survey, Reston, Virginia: 2015
}

For more information on the USGS - the Federal source for science about the Earth, its natural and living resources, natural hazards, and the environment—visit http://www.usgs.gov or call 1-888-ASK-USGS.

For an overview of USGS information products, including maps, imagery, and publications, visit http://www.usgs.gov/pubprod/.

Any use of trade, firm, or product names is for descriptive purposes only and does not imply endorsement by the U.S. Government.

Although this information product, for the most part, is in the public domain, it also may contain copyrighted materials as noted in the text. Permission to reproduce copyrighted items must be secured from the copyright owner.

Suggested citation:

Musser, J.W., 2015, Flood-inundation maps for South Fork Peachtree Creek from the Brockett Road bridge to the Willivee Drive bridge, DeKalb County, Georgia: U.S. Geological Survey Scientific Investigations Map 3347, 13 sheets, 10-p. pamphlet, http://dx.doi.org/10.3133/sim3347.

ISSN 2329-132X (online) 


\section{Contents}

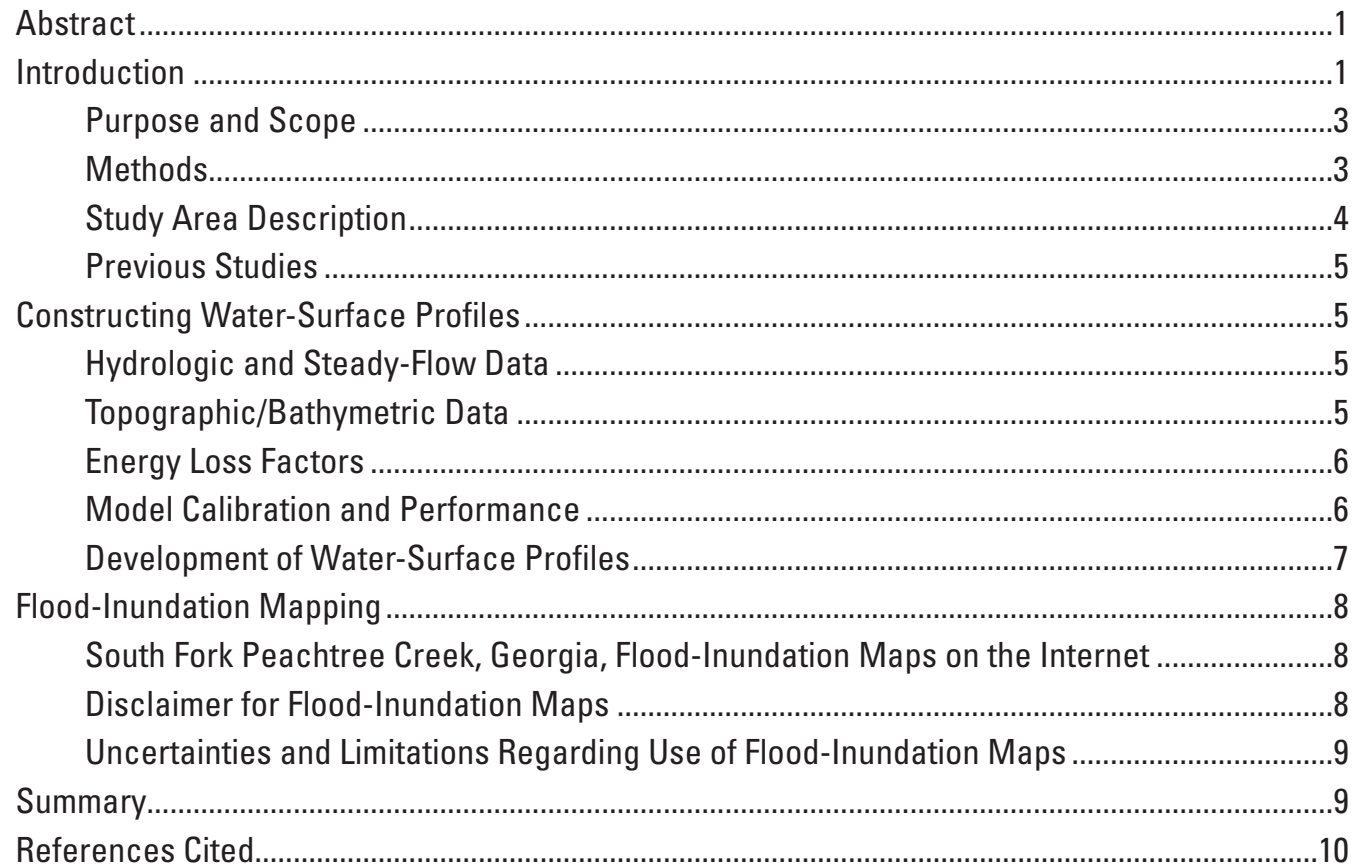

\section{Figures}

1. Map showing location of study reach for South Fork Peachtree Creek and location of U.S. Geological Survey streamgages and National Weather Service forecast sites, DeKalb County, Georgia ...

2. Map showing South Fork Peachtree Creek bridge crossings, model extent, and direction of surface-water flow, DeKalb County, Georgia .

\section{Tables}

1. Site information for the U.S. Geological Survey streamgages in the South Fork Peachtree Creek basin in DeKalb County, Georgia...

2. Comparison of hydraulic-model output and high-water marks obtained along South Fork Peachtree Creek from a flow peak of 1,410 cubic feet per second at a stage of 8.79 feet at the South Fork Peachtree at Casa Drive, near Clarkston, Georgia streamgage.

3. Comparison of hydraulic-model output and water-surface elevations at the South Fork Peachtree at Casa Drive, near Clarkston, Georgia, streamgage

4. Stages (and water-surface elevations) with corresponding discharge estimates for selected simulated water-surface profiles at selected locations for the South Fork Peachtree at Casa Drive, near Clarkston, Georgia, streamgage

5. Stream stages (and water-surface elevations) at the South Fork Peachtree at Casa Drive, near Clarkston, Georgia, streamgage and corresponding map-sheet numbers in this report 


\section{Sheets (Each sheet has individual pdf file available for downloading from http://dx.doi.org/10.3133/sim3347).}

1-13. Maps showing flood-inundation of South Fork Peachtree Creek in DeKalb County, Georgia, corresponding to a stage and an elevation (North American Vertical Datum of 1988) as listed below at U.S. Geological Survey streamgage South Fork Peachtree at Casa Drive, near Clarkston, Georgia (02336152)

1. Gage height of 6.0 feet and an elevation of 938.2 feet

2. Gage height of 6.5 feet and an elevation of 938.7 feet

3. Gage height of 7.0 feet and an elevation of 939.2 feet

4. Gage height of 7.5 feet and an elevation of 939.7 feet

5. Gage height of 8.0 feet and an elevation of 940.2 feet

6. Gage height of 8.5 feet and an elevation of 940.7 feet

7. Gage height of 9.0 feet and an elevation of 941.2 feet

8. Gage height of 9.5 feet and an elevation of 941.7 feet

9. Gage height of 10.0 feet and an elevation of 942.2 feet

10. Gage height of 10.5 feet and an elevation of 942.7 feet

11. Gage height of 11.0 feet and an elevation of 943.2 feet

12. Gage height of 11.5 feet and an elevation of 943.7 feet

13. Gage height of 12.0 feet and an elevation of 944.2 feet 


\section{Conversion Factors}

[Inch/Pound to International System of Units]

\begin{tabular}{lcc}
\hline & Bultiply & To obtain \\
\hline foot $(\mathrm{ft})$ & Length & meter $(\mathrm{m})$ \\
mile $(\mathrm{mi})$ & 0.3048 & kilometer $(\mathrm{km})$ \\
\hline & 1.609 & \\
\hline square mile $\left(\mathrm{mi}^{2}\right)$ & Area & square kilometer $\left(\mathrm{km}^{2}\right)$ \\
\hline & 2.590 & \\
\hline cubic foot per second $\left(\mathrm{ft}^{3} / \mathrm{s}\right)$ & Flow rate & cubic meter per second $\left(\mathrm{m}^{3} / \mathrm{s}\right)$ \\
\hline & 0.02832 & \\
\hline foot per mile $(\mathrm{ft} / \mathrm{mi})$ & Hydraulic gradient & meter per kilometer $(\mathrm{m} / \mathrm{km})$ \\
\hline
\end{tabular}

\section{Datum}

Vertical coordinate information is referenced to the North American Vertical Datum of 1988 (NAVD 88).

Horizontal coordinate information is referenced to the North American Datum of 1983 (NAD 83).

Elevation, as used in this report, refers to distance above the vertical datum.

Stage, as used in this report, is the height of water surface above an arbitrary datum established at the gage (gage datum).

\section{Abbreviations}

$\begin{array}{ll}\text { AHPS } & \text { Advanced Hydrologic Prediction Service } \\ \text { DFIRM } & \text { Digital Flood Insurance Rate Map } \\ \text { FEMA } & \text { Federal Emergency Management Agency } \\ \text { GIS } & \text { geographic information system } \\ \text { lidar } & \text { light detection and ranging } \\ \text { NWS } & \text { National Weather Service } \\ \text { USGS } & \text { U.S. Geological Survey }\end{array}$




\section{Acknowledgments}

The author wishes to thank DeKalb County, Georgia, for funding the operation and maintenance of the streamgage used for this study. Special thanks are given to the National Weather Service for their continued support to the U.S. Geological Survey flood-inundation mapping initiative. 


\title{
Flood-Inundation Maps for South Fork Peachtree Creek From the Brockett Road Bridge to the Willivee Drive Bridge, DeKalb County, Georgia
}

\author{
By Jonathan W. Musser
}

\begin{abstract}
Digital flood-inundation maps for a 5.3-mile reach of South Fork Peachtree Creek that extends from about 500 feet above the Brockett Road bridge to the Willivee Drive bridge were developed by the U.S. Geological Survey (USGS) in cooperation with DeKalb County, Georgia. The flood-inundation maps, which can be accessed through the USGS Flood Inundation Mapping Science Web site at http://water.usgs.gov/osw/flood_inundation/, depict estimates of the areal extent and depth of flooding corresponding to selected water levels (stages) at the USGS streamgage at South Fork Peachtree at Casa Drive, near Clarkston, Georgia (02336152). Real-time stage information from this USGS streamgage may be obtained at http://waterdata.usgs.gov/ and can be used in conjunction with these maps to estimate near real-time areas of inundation. The National Weather Service (NWS) is incorporating results from this study into the Advanced Hydrologic Prediction Service (AHPS) floodwarning system (http:/water.weather.gov/ahps/).

A one-dimensional step-backwater model was developed using the U.S. Army Corps of Engineers HEC-RAS software for South Fork Peachtree Creek and was used to compute flood profiles for a 5.3-mile reach of South Fork Peachtree Creek. The model was calibrated using the most current (2015) stage-discharge relation at the USGS streamgage South Fork Peachtree at Casa Drive, near Clarkston, Georgia (02336152). The hydraulic model was then used to simulate 13 water-surface profiles at 0.5 -foot intervals at the South Fork Peachtree Creek near Clarkston streamgage. The profiles ranged from just above bankfull stage (6.0 feet) to approximately 3.21 feet above the highest recorded water level (12.0 feet). The simulated water-surface profiles were then combined with a geographic information system digital elevation model - derived from light detection and ranging data having a 5.0-foot horizontal resolution - to delineate the area flooded at each 0.5 -foot interval of stream stage.
\end{abstract}

The availability of these flood-inundation maps, when combined with real-time stage information from USGS streamgages, provides emergency management personnel and residents with critical information during flood-response activities, such as evacuations and road closures, in addition to post-flood recovery efforts.

\section{Introduction}

DeKalb County, Georgia (Ga.), is an urban and suburban community with an estimated population of 722,161 in 2014 (U.S. Census Bureau, [2015]; fig. 1). Development on the South Fork Peachtree Creek flood plain within the county is varied with a mix of residential, recreational, and commercial structures; and areas of grass fields, wetlands, and forest (Homer and others, 2015). South Fork Peachtree Creek flows generally west through DeKalb County and the City of Clarkston, Ga., which is located in the central part of DeKalb County (fig. 1). Peak flood flows in excess of 1,000 cubic feet per second $\left(\mathrm{ft}^{3} / \mathrm{s}\right)$ were recorded at the Clarkston, Ga., streamgage (02336152) site in 2010, 2013, and 2014; the largest peak flow was recorded on August 21, 2013, at $1,410 \mathrm{ft}^{3} / \mathrm{s}$.

Before this study, DeKalb County officials relied on several information sources (available on the Internet) to make decisions on how best to alert the public and mitigate flood damages along South Fork Peachtree Creek. One source of information was the Federal Emergency Management Agency (FEMA) Digital Flood Insurance Rate Map (DFIRM) (Federal Emergency Management Agency, [2013]). A second source of information was the U.S. Geological Survey (USGS) streamgage (table 1), South Fork Peachtree at Casa Drive near Clarkston, Ga. (02336152), from which current or historical water levels (stage) can be obtained (through the USGS National Water Information System Web site, http://waterdata.usgs.gov/nwis). 

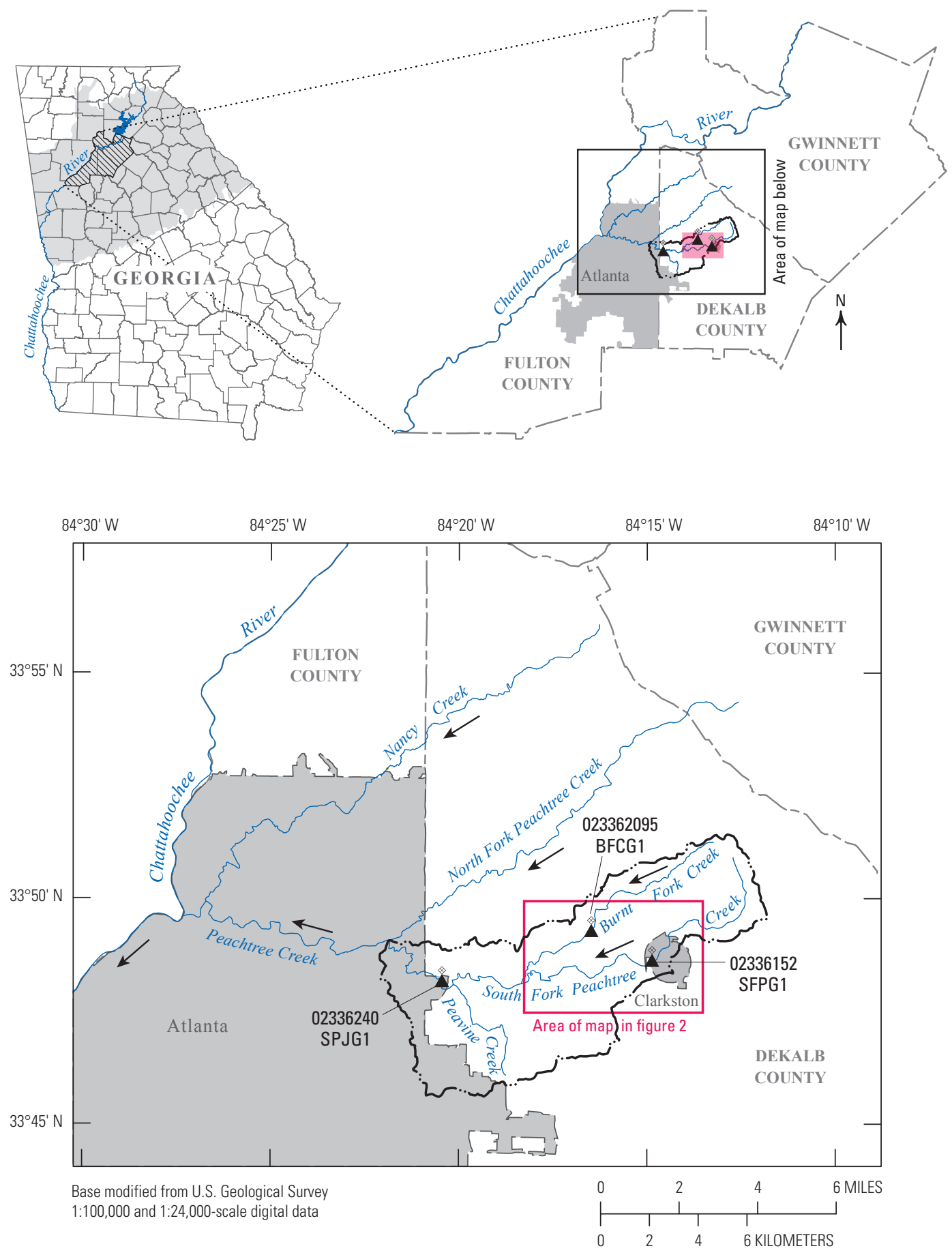

EXPLANATION

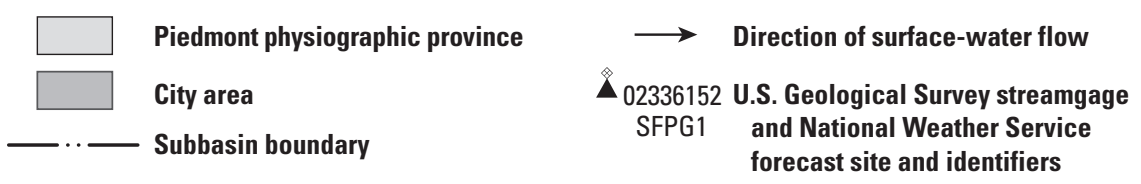

Figure 1. Location of study reach for South Fork Peachtree Creek and location of U.S. Geological Survey streamgages and National Weather Service forecast sites, DeKalb County, Georgia. 
Table 1. Site information for the U.S. Geological Survey streamgages in the South Fork Peachtree Creek basin in DeKalb County, Georgia.

[See figure 1 for station location; USGS, U.S. Geological Survey; Ga., Georgia; ft, feet]

\begin{tabular}{|c|c|c|c|c|c|c|}
\hline \multirow{2}{*}{ Station name } & \multirow{2}{*}{$\begin{array}{l}\text { USGS } \\
\text { station } \\
\text { number }\end{array}$} & \multirow{2}{*}{$\begin{array}{l}\text { Drainage area, } \\
\text { square miles }\end{array}$} & Latitude & Longitude & \multirow[b]{2}{*}{ Period of record } & \multirow{2}{*}{$\begin{array}{c}\text { Maximum recorded } \\
\text { stage at streamgage } \\
\text { and date }\end{array}$} \\
\hline & & & \multicolumn{2}{|c|}{ (degrees, minutes, seconds) } & & \\
\hline $\begin{array}{c}\text { South Fork Peachtree at Casa } \\
\text { Drive, near Clarkston, Ga. }\end{array}$ & 02336152 & 5.62 & $33^{\circ} 48^{\prime} 38^{\prime \prime}$ & $84^{\circ} 14^{\prime} 53^{\prime \prime}$ & $\begin{array}{l}2012 \text { to current } \\
\text { year (2015) }\end{array}$ & $\begin{array}{c}8.79 \mathrm{ft} \\
\text { Aug. } 21,2013\end{array}$ \\
\hline $\begin{array}{l}\text { S.F. Peachtree Creek Johnson } \\
\text { Road, near Atlanta, Ga. }\end{array}$ & 02336240 & 27.6 & $33^{\circ} 48^{\prime} 10^{\prime \prime}$ & $84^{\circ} 2^{\prime} 27^{\prime \prime}$ & $\begin{array}{l}2003 \text { to current } \\
\text { year }(2015)\end{array}$ & $\begin{array}{c}16.10 \mathrm{ft} \\
\text { Sept. } 16,2004\end{array}$ \\
\hline
\end{tabular}

Stage is the height of the water surface above an arbitrary datum established at the gage (gage datum). A third source of information used by DeKalb County officials was the National Weather Service (NWS) South Fork Peachtree Creek at Clarkston streamgage (forecast site SFPG1) through the Advanced Hydrologic Prediction Service (AHPS) Web site at http:/water.weather.gov/ahps/; however, NWS forecasts are not available for this site.

Although USGS real-time stages are particularly useful for residents in the immediate vicinity of a streamgage, the data are of limited use to residents farther upstream or downstream because the water-surface elevation is not constant everywhere along an entire stream channel. Likewise, depth varies locally along stream channels, and FEMA and State emergency management mitigation teams or property owners typically lack information related to water depth in areas that are not near USGS streamgages or NWS flood-forecast points. To help guide the general public in taking individual safety precautions and provide local officials with a tool to help efficiently manage emergency flood operations and flood-mitigation efforts, a series of digital flood-inundation maps for a 5.3-mile (mi) reach of South Fork Peachtree Creek was developed by the USGS in cooperation with DeKalb County, Ga.

\section{Purpose and Scope}

The purpose of this report is to describe the development of a series of estimated flood-inundation maps for South Fork Peachtree Creek in DeKalb County, Ga. The maps and other flood information are available on the USGS Flood Inundation Mapping Science Web site at http://water.usgs.gov/ osw/flood_inundation/ and the previously mentioned NWS AHPS We $\bar{b}$ site. Internet users can select estimated inundation maps that would be close to (1) current stage at the USGS streamgage near Clarkston, Ga. (02336152), or (2) other desired stream stages.
The scope of the study was limited to a 5.3-mi reach of South Fork Peachtree Creek that extends from about 500 feet (ft) above the Brockett Road bridge to the Willivee Drive bridge (fig. 2). Tasks specific to development of the floodinundation maps were (1) analysis of the flow and stage data collected at one USGS streamgage, South Fork Peachtree at Casa Drive near Clarkston, Ga. (02336152) (table 1); (2) collection of topographic data and geometric data (for flood plains, flow-control structures, bridges, and the stream channel) throughout the study reach; (3) determination of energy-loss factors (roughness coefficients) in the stream channel and flood plain; (4) computation of water-surface profiles using the U.S. Army Corps of Engineers Hydrologic Engineering Center's River Analysis System (HEC-RAS) computer program (U.S. Army Corps of Engineers, Hydrologic Engineering Center, 2010); (5) production of estimated flood-inundation maps based on simulated stream stages at the South Fork Peachtree at Casa Drive, near Clarkston streamgage (02336152) using the U.S. Army Corps of Engineers HEC-GeoRAS computer program (U.S. Army Corps of Engineers, Hydrologic Engineering Center, 2014) and a geographic information system (GIS); and (6) development of a Web site interface that links to USGS real-time streamgage information.

\section{Methods}

Methods used generally are cited from previously published reports (Bales and others, 2007; Whitehead and Ostheimer, 2009). If techniques varied substantially from previously documented methods because of local hydrologic conditions or available data, they are described in detail in this report. Inundation maps were produced for 13 water-surface profiles referenced to the stage at the streamgage South Fork Peachtree at Casa Drive near Clarkston (02336152). These profiles ranged from about bankfull stage $(6.0 \mathrm{ft})$ to $3.21 \mathrm{ft}$ above the maximum water level recorded at the streamgage $(12.0 \mathrm{ft})$. 


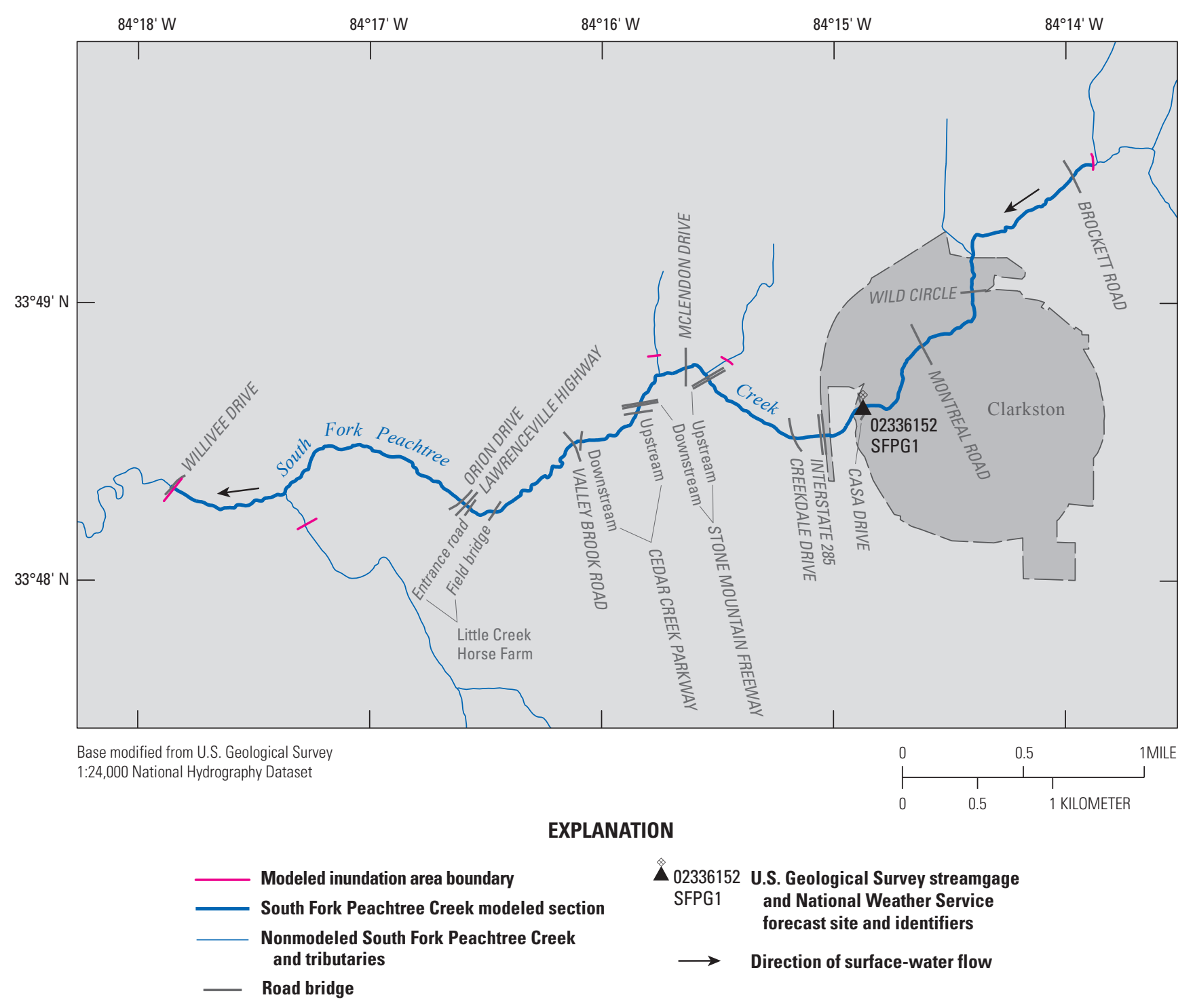

Figure 2. South Fork Peachtree Creek bridge crossings, model extent, and direction of surface-water flow, DeKalb County, Georgia.

\section{Study Area Description}

South Fork Peachtree Creek is in northern Georgia in the Piedmont physiographic province (Clark and Zisa, 1976). The drainage area ranges from 4.03 square miles $\left(\mathrm{mi}^{2}\right)$ at the upstream end of the study reach about $500 \mathrm{ft}$ upstream from the Brockett Road bridge to $5.62 \mathrm{mi}^{2}$ at the South Fork Peachtree at Casa Drive near Clarkston streamgage (02336152) to $11.2 \mathrm{mi}^{2}$ at the Willivee Drive bridge, which is at the downstream end of the study reach (fig. 2). South Fork Peachtree Creek is completely in DeKalb County, Ga. (fig. 1). South Fork Peachtree Creek generally flows west through DeKalb County, Ga., until it joins with North Fork Peachtree Creek to form Peachtree Creek in the City of Atlanta in Fulton County, Ga. Peachtree Creek then empties into the Chattahoochee River. The major tributaries flowing into South Fork Peachtree Creek are Burnt Fork Creek and Peavine Creek. Other streamgages in the South Fork Peachtree Creek basin are Burnt Fork Creek at Millwood Way, near Clarkston, Ga. (023362095), and S.F. Peachtree Creek Johnson Road, near Atlanta, Ga. (02336240). Nancy Creek is a major tributary that flows into Peachtree Creek. The South Fork Peachtree Creek basin terrain is gently rolling with stream valleys that are fairly deep and narrow and lie 100 to $200 \mathrm{ft}$ below the narrow, rounded stream divides (Clark and Zisa, 1976). The study reach is about $5.3 \mathrm{mi}$ long, is fairly consistent in slope and width with some local variations, and has an average channel slope of about 15.5 feet per mile (ft/mi). The land that is contiguous to the study reach is mostly classified as developed with some areas classified as forest and wetlands (Fry and others, 2011). The main channel within the study reach has 16 road bridges that cross the channel and the adjacent flood plain. 


\section{Previous Studies}

The current (as of 2015) DFIRM for DeKalb County, Ga., was published on May 16, 2013 (Federal Emergency Management Agency, [2013]). The HEC-RAS model of South Fork Peachtree Creek, which was used in the publication of the DFIRM, was obtained in 2015 from Sam Fleming at Dewberry (written commun., February 2015), an engineering firm contracted by FEMA to model specific flood stages on South Fork Peachtree Creek. The cross sections, stream channel, and bridge details within the study reach were taken from the existing HEC-RAS models and used as a starting point for creation of the model developed for this study.

Similar studies that provide flood-inundation maps for a range of stream stages have been completed by the USGS in Albany, Ga., for the Flint River (Musser and Dyar, 2007); Atlanta, Ga., for Peachtree Creek (Musser, 2012a); Gwinnett County, Ga., for Suwanee Creek (Musser, 2012b); Cobb County, Ga., for Sweetwater Creek (Musser, 2012c); and Alpharetta and Roswell, Ga., for Big Creek (Musser, 2015). The methods for the Flint River model used a finite-element, two-dimensional model, which differed from those used to develop the South Fork Peachtree Creek model. The methods used for the Peachtree Creek, Suwanee Creek, Sweetwater Creek, and Big Creek models were similar to those used to develop the South Fork Peachtree Creek model.

\section{Constructing Water-Surface Profiles}

The water-surface profiles used to produce the 13 floodinundation maps developed for this study were computed using HEC-RAS, version 4.1 (U.S. Army Corps of Engineers, Hydrologic Engineering Center, 2010). The HEC-RAS is a one-dimensional step-backwater model for simulation of water-surface profiles with gradually varied, steady-state or unsteady-state flow computation options. For this study, the HEC-RAS analysis was completed by using the steady-state flow computation option.

\section{Hydrologic and Steady-Flow Data}

The hydrologic network in the study area consists of one USGS streamgage that is operated within the study reach as well as one USGS streamgage downstream on South Fork Peachtree Creek and one USGS streamgage on Burnt Fork Creek (fig. 1; table 1). Water level (stage) is measured continuously at each site, and continuous records of streamflow are computed. Stage is the height of the water surface above an arbitrary datum established at the gage (gage datum). All watersurface elevations are referenced to the North American Vertical Datum of 1988 (NAVD 88). The streamgages are equipped with a satellite radio transmitter that allows data to be transmitted routinely and made available on the Internet within 1 hour of collection. The streamgages are also equipped with a recording rain gage. Steady-flow data consisted of flow regime (stage and discharge values) and peak discharge information. Steady-flow data for the study reach were calibrated in the model using the stage-discharge relation at the South Fork Peachtree at Casa Drive near Clarkston streamgage (02336152). Downstream boundary conditions in the model were determined using a normal depth based on slope (U.S. Army Corps of Engineers, Hydrologic Engineering Center, 2010).

\section{Topographic/Bathymetric Data}

The cross sections from the existing HEC-RAS DFIRM model of Big Creek, obtained from Dewberry, were used as a starting point for the model developed in this study. Hereafter, the term "DFIRM" will be used to describe the previous version of the model as obtained from Dewberry (Sam Fleming, written commun., February 2015). Additional cross sections were added to the USGS model where the distance between cross sections was more than $500 \mathrm{ft}$ in the DFIRM model and in locations where there was a substantial change in the flood plain such as width or change in roughness. The in-channel elevations of these new cross sections were calculated by extracting the in-channel part of an original cross section and lowering or raising it based on the channel slope between two adjacent original cross sections. The overbank elevations of the new cross sections were calculated from a raster elevation dataset. The source for the raster elevation was a $5.0-\mathrm{ft}$ by $5.0-\mathrm{ft}$ cell raster from light detection and ranging (lidar) data obtained from the Atlanta Regional Commission. The raster elevation did not contain any metadata describing the accuracy. The flow lengths between cross sections were recomputed after the new cross sections were added to the model. Additionally, all ineffective flow areas were reevaluated and recalculated for all cross sections.

Various drainage structures (bridges, culverts, roadway embankments, levees, and dams) in and along the stream affect or have the potential to affect water-surface elevations during floods. To properly account for these features in the model, structural dimensions of 16 bridges were measured and surveyed in the field. The geometry of these bridge structures was already present in the existing DFIRM HEC-RAS model. Site visits were made to all bridges to confirm the accuracy of the bridge geometry in the existing DFIRM model. From upstream to downstream, the bridges are Brockett Road, Wild Circle, Montreal Road, Casa Drive, Interstate 285, Creekdale Drive, Stone Mountain Freeway (upstream), McLendon Drive, Stone Mountain Freeway (downstream), Cedar Creek Parkway (upstream), Cedar Creek Parkway (downstream), Valley Brook Road, Little Creek Horse Farm field bridge, Little Creek Horse Farm entrance road, Lawrenceville Highway, and Orion Drive. The Willivee Drive bridge is not included as the model ends just upstream from the bridge (fig. 2).

A detailed description of the methods used to acquire and process the topographic and bathymetric data is provided in Bales and others (2007). 


\section{Energy Loss Factors}

Field observations and high-resolution aerial photographs were used to select initial (precalibration) Manning's roughness coefficients (" $n$ " values) for energy (friction) loss calculations. The final Manning's $n$ values ranged from 0.03 in one cross section to 0.1 in the part of the model upstream from the Casa Drive bridge for the main channel. The Manning's $n$ values ranged from 0.04 (light vegetation areas) to 0.11 (forested areas with heavy undergrowth) for the overbank areas modeled in the reach.

\section{Model Calibration and Performance}

The hydraulic model was calibrated using the most current (2015) stage-discharge relation (http://waterdata.usgs. gov/nwis) at the South Fork Peachtree at Casa Drive near Clarkston streamgage (02336152). This streamgage has been in operation since 2012, and the maximum peak discharge was recorded at the site on August 21, 2013. The peak discharge recorded was $1,410 \mathrm{ft}^{3} / \mathrm{s}$ at a stage of $8.79 \mathrm{ft}$. The flow remains in the main channel at the streamgage location up to a gage height of $12.0 \mathrm{ft}$, so flow values for the stages from $8.79 \mathrm{ft}$ to $12.0 \mathrm{ft}$ were obtained using a straight line extension of the rating curve above $8.79 \mathrm{ft}$.

The model was calibrated by adjusting Manning's $n$ value of the channel until the results of the hydraulic computations closely agreed with high-water marks that were obtained using electronic water-level sensors that were deployed at various bridges during the August 21, 2013, event. High-water mark locations and elevations that were obtained are in table 2. The minimum recorded water level was $895.5 \mathrm{ft}$ at the Willivee Drive Bridge sensor. The water level did not reach the water-level sensor during the August 21, 2013, event; thus, the water level peaked at an elevation below $895.5 \mathrm{ft}$ at the Willivee Drive bridge. DeKalb County was unable to provide more flooding information in this area. The initial model calibration attempts resulted in elevations of about $898 \mathrm{ft}$ just upstream from the Willivee Drive bridge. This elevation is at least $2.5 \mathrm{ft}$ higher than the known water surface at this location. The area between Orion Drive and Willivee Drive has some wetland areas, which could possibly reduce flow peaks downstream. As a first step to lower the water-surface elevation upstream from Willivee Drive, the flows $850 \mathrm{ft}$ downstream from Orion Drive were not increased. The peak flow at S.F. Peachtree Creek Johnson Road, near Atlanta streamgage (02336240), was only $1,990 \mathrm{ft}^{3} / \mathrm{s}$ on August 21, 2013, which also supports not increasing the flows downstream from Orion Drive. The adjustment in the flows $850 \mathrm{ft}$ below Orion Drive did result in a small drop in water-surface elevation, but not enough to bring the water surface below $895.5 \mathrm{ft}$. The next step was to remove the Willivee Drive bridge from the model. Once Willivee Drive bridge was removed from the model, and the downstream boundary condition was adjusted, the simulated water-surface elevation $60 \mathrm{ft}$ upstream from the Willivee Drive bridge was $894.7 \mathrm{ft}$, which is below the target elevation of $895.5 \mathrm{ft}$. The results of the calibration are shown in table 2. Upstream from Orion Drive, the model calibrated between -0.2 and $0.2 \mathrm{ft}$. Downstream from Orion Drive, the results have a much greater uncertainty because of the lack of high-water mark information for calibration.

Once the model was calibrated, the simulated watersurface elevations from the model were compared to the expected water-surface elevations for each 0.5 -ft stage interval at the South Fork Peachtree at Casa Drive, near Clarkston streamgage (02336152). The differences were small enough that no additional calibration was needed for stages of $8.0 \mathrm{ft}$ and above. Some additional calibration by adjusting the Manning's $n$ value of the channel was needed for stages ranging from 6.0 to $7.5 \mathrm{ft}$. The differences between measured and simulated water levels for models calibrated to stages

Table 2. Comparison of hydraulic-model output and high-water marks obtained along South Fork Peachtree Creek from a flow peak of 1,410 cubic feet per second at a stage of 8.79 feet at the South Fork Peachtree at Casa Drive, near Clarkston, Georgia streamgage (02336152).

[Elevation listed in feet above the North American Vertical Datum of 1988; ft, foot; <, less than; - , not available]

\begin{tabular}{|c|c|c|c|}
\hline Location & $\begin{array}{l}\text { Actual water- } \\
\text { surface elevations } \\
\text { (ft) }\end{array}$ & $\begin{array}{l}\text { Modeled water- } \\
\text { surface elevations } \\
\text { (ft) }\end{array}$ & $\begin{array}{l}\text { Elevation } \\
\text { difference } \\
\text { (ft) }\end{array}$ \\
\hline 100 feet upstream from Wild Circle bridge & 956.9 & 956.7 & -0.2 \\
\hline Downstream side of Wild Circle bridge & 956.1 & 956.0 & -0.1 \\
\hline $\begin{array}{l}\text { South Fork Peachtree at Casa Drive, near Clarkston, Georgia } \\
\text { streamgage }(02336152)\end{array}$ & 941.0 & 941.1 & 0.1 \\
\hline $60 \mathrm{ft}$ upstream from McLendon Drive bridge & 929.4 & 929.5 & 0.1 \\
\hline $50 \mathrm{ft}$ upstream from Little Creek Horse Farm entrance road bridge & 912.2 & 912.4 & 0.2 \\
\hline Downstream side of Orion Drive bridge & 910.8 & 910.8 & 0.0 \\
\hline $60 \mathrm{ft}$ upstream from Willivee Drive bridge & $<895.5$ & 894.7 & - \\
\hline
\end{tabular}


were between -0.1 and $0.2 \mathrm{ft}$ (table 3 ). Details on techniques used in model development and calibration are provided in Bales and others (2007).

\section{Development of Water-Surface Profiles}

Profiles were developed for 13 stages at 0.5 - $\mathrm{ft}$ intervals between 6.0 and $12.0 \mathrm{ft}$ as referenced to the South Fork Peachtree at Casa Drive, near Clarkston streamgage (02336152). Discharges corresponding to profiles at stages were obtained from the most current (2015) stage-discharge relation in use at the streamgage (rating no. 1.0, effective February 2, 2010). These discharge values were used as input in the model. The discharges for all profiles were adjusted along South Fork Peachtree Creek primarily at junctions with smaller tributaries. These discharge values were calculated based on a ratio of streamflow to drainage area raised to the 0.57 power (Gotvald and Knaak, 2011). Upstream from the streamgage, the discharge values were smaller than at the streamgage, and downstream they were larger. The flow values were not increased $850 \mathrm{ft}$ downstream from Orion Drive for water-surface elevation calibration as discussed in "Model Calibration and Performance."

Simulated stage and discharge estimates for selected locations and profiles are in table 4. A normal depth based on slope of the streambed method was used for the downstream boundary conditions (U.S. Army Corps of Engineers, Hydrologic Engineering Center, 2010). All streamflow and water-elevation data used for the model are available in the USGS National Water Information System at http://waterdata.usgs.gov/nwis.
Table 3. Comparison of hydraulic-model output and watersurface elevations at the South Fork Peachtree at Casa Drive, near Clarkston, Georgia, streamgage (02336152).

[Stage listed in feet above the gage datum; elevation listed in feet above the North American Vertical Datum of 1988; ft, foot]

\begin{tabular}{|cccc|}
\hline $\begin{array}{c}\text { Stage } \\
\text { (ft) }\end{array}$ & $\begin{array}{c}\text { Actual water- } \\
\text { surface } \\
\text { elevations } \\
\text { (ft) }\end{array}$ & $\begin{array}{c}\text { Modeled } \\
\text { water-surface } \\
\text { elevations } \\
\text { (ft) }\end{array}$ & $\begin{array}{c}\text { Elevation } \\
\text { difference } \\
\text { (ft) }\end{array}$ \\
\hline 6.0 & 938.2 & 938.3 & 0.1 \\
\hline 6.5 & 938.7 & 938.9 & 0.2 \\
\hline 7.0 & 939.2 & 939.3 & 0.1 \\
\hline 7.5 & 939.7 & 939.8 & 0.1 \\
\hline 8.0 & 940.2 & 940.4 & 0.2 \\
\hline 8.5 & 940.7 & 940.8 & 0.1 \\
\hline 9.0 & 941.2 & 941.3 & 0.1 \\
\hline 9.5 & 941.7 & 941.9 & 0.2 \\
\hline 10.0 & 942.2 & 942.4 & 0.2 \\
\hline 10.5 & 942.7 & 942.8 & 0.1 \\
\hline 11.0 & 943.2 & 943.3 & 0.1 \\
\hline 11.5 & 943.7 & 943.7 & 0.0 \\
\hline 12.0 & 944.2 & 944.1 & -0.1 \\
\hline
\end{tabular}

Table 4. Stages (and water-surface elevations) with corresponding discharge estimates for selected simulated water-surface profiles at selected locations for the South Fork Peachtree at Casa Drive, near Clarkston, Georgia, streamgage (02336152).

[NAVD 88; North American Vertical Datum of 1988]

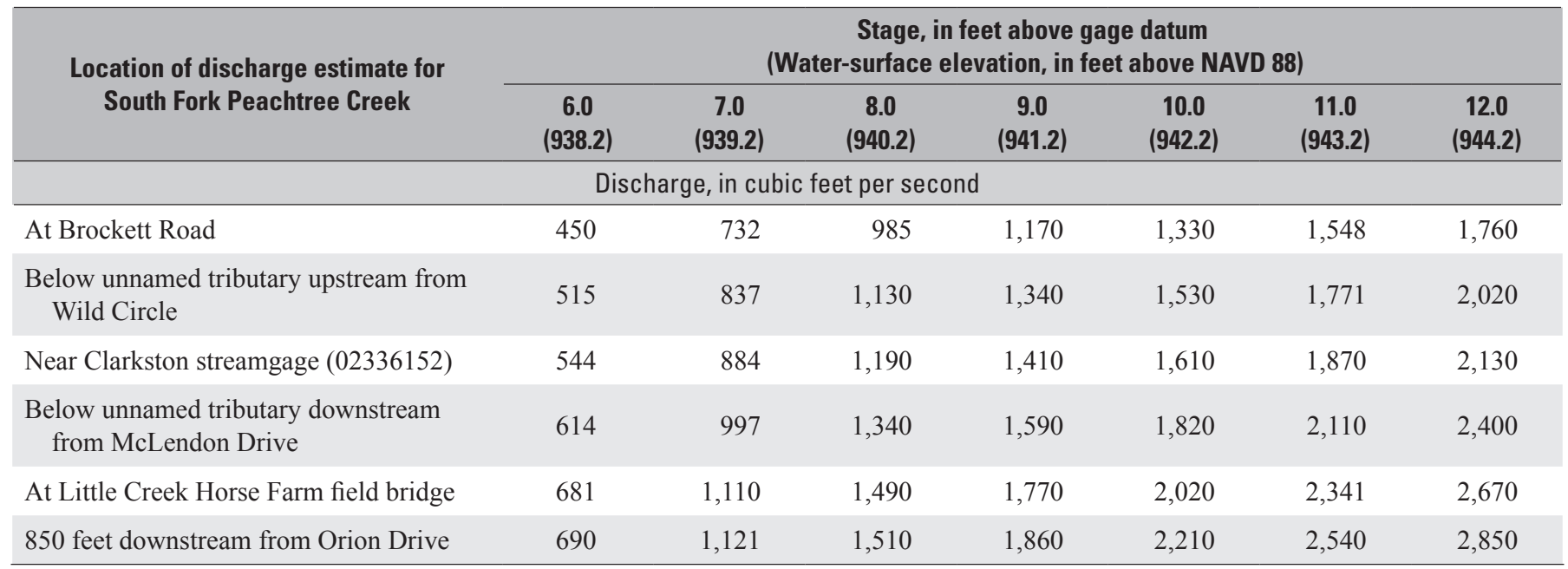




\section{Flood-Inundation Mapping}

Flood-inundation maps were created based on simulated water-surface elevations at the South Fork Peachtree at Casa Drive, near Clarkston streamgage (02336152), which has the NWS designation SFPG1. The maps were created in a GIS by combining the water-surface profiles and digital elevation model data. The digital elevation model data are from a $5.0-\mathrm{ft}$ by $5.0-\mathrm{ft}$ cell raster derived from lidar data obtained from the Atlanta Regional Commission. Estimated flood-inundation boundaries for each simulated profile were developed with HEC-GeoRAS software (U.S. Army Corps of Engineers, Hydrologic Engineering Center, 2014). HEC-GeoRAS is a set of procedures, tools, and utilities for processing geospatial data in ArcGIS (Esri, [2015]) by using a graphical user interface (Whitehead and Ostheimer, 2009). The interface allows the preparation of geometric data for import into HEC-RAS and processes simulation results exported from HEC-RAS (U.S. Army Corps of Engineers, Hydrologic Engineering Center, 2010). The HEC-GeoRAS results were modified to ensure a hydraulically reasonable transition of the boundary between modeled cross sections relative to the contour data for the land surface (Whitehead and Ostheimer, 2009). The resulting inundation maps have a vertical accuracy of about $0.5 \mathrm{ft}$ in the area upstream from Orion Drive. The maps show estimated floodinundated areas overlain on high-resolution, georeferenced, aerial photographs of the study area for each of the water-surface profiles that were generated by the hydraulic model. The sheet numbers corresponding to each 0.5 -ft stage increment at the South Fork Peachtree Creek streamgage are in table 5.

\section{South Fork Peachtree Creek, Georgia, Flood- Inundation Maps on the Internet}

A USGS Flood Inundation Mapping Science World Wide Web portal (http://water.usgs.gov/osw/flood_inundation/) has been established by the USGS to provide estimated flood-inundation information to the public. The maps from this study are available in several commonly used electronic file formats that can be downloaded from that portal. Each stream reach displayed on the Web site contains links to the USGS National Water Information System graphs of the current stage and streamflow at the USGS South Fork Peachtree at Casa Drive near Clarkston, Ga., streamgage (02336152) to which the inundation maps are referenced. A link also is provided to the NWS AHPS Web site (http:/water.weather.gov/ahps/). The estimated floodinundation maps are displayed in sufficient detail to note the extent of flooding with respect to individual structures so that preparations for flooding and decisions for emergency response can be completed efficiently.

\section{Disclaimer for Flood-Inundation Maps}

Inundated areas shown should not be used for navigation, regulatory, permitting, or other legal purposes. The USGS provides these maps "as-is" for a quick-reference, emergency planning tool but assumes no legal liability or responsibility resulting from the use of this information.

Table 5. Stream stages (and water-surface elevations) at the South Fork Peachtree at Casa Drive, near Clarkston, Georgia, streamgage (02336152) and corresponding map-sheet numbers in this report.

[Values 6.0-12.0 represent stage, in feet above the gage datum. Values in parentheses (938.2-944.2) represent surface-water elevation in feet above the North American Vertical Datum of 1988; - , not applicable]

\begin{tabular}{|c|c|c|c|c|c|c|c|}
\hline \multicolumn{8}{|c|}{ South Fork Peachtree Creek near Clarkston, Georgia } \\
\hline $\begin{array}{l}\text { Stage (water-surface } \\
\text { elevation) }\end{array}$ & $\begin{array}{c}6.0 \\
(938.2)\end{array}$ & $\begin{array}{c}6.5 \\
(938.7)\end{array}$ & $\begin{array}{c}7.0 \\
(939.2)\end{array}$ & $\begin{array}{c}7.5 \\
(939.7)\end{array}$ & $\begin{array}{c}8.0 \\
(940.2)\end{array}$ & $\begin{array}{c}8.5 \\
(940.7)\end{array}$ & $\begin{array}{c}9.0 \\
(941.2)\end{array}$ \\
\hline $\begin{array}{l}\text { Stage (water-surface } \\
\text { elevation) }\end{array}$ & $\begin{array}{c}9.5 \\
(941.7)\end{array}$ & $\begin{array}{c}10.0 \\
(942.2)\end{array}$ & $\begin{array}{c}10.5 \\
(942.7)\end{array}$ & $\begin{array}{c}11.0 \\
(943.2)\end{array}$ & $\begin{array}{c}11.5 \\
(943.7)\end{array}$ & $\begin{array}{c}12.0 \\
(944.2)\end{array}$ & - \\
\hline
\end{tabular}




\section{Uncertainties and Limitations Regarding Use of Flood-Inundation Maps}

The flood boundaries shown were estimated based on water stages/streamflows at the USGS streamflow gaging station, South Fork Peachtree at Casa Drive, near Clarkston, Ga. (02336152), steady-state hydraulic modeling (assuming unobstructed flow), and a digital elevation model. The hydraulic model reflects the land-cover characteristics and any bridge, dam, levee, or other hydraulic structures existing in July 2015. Unique meteorological factors (timing and distribution of storm) could cause actual streamflows along the modeled reach to vary from those assumed during a flood, which may lead to deviations from the water-surface elevations and inundation boundaries shown here. Additional areas may be flooded due to unanticipated backwater from major tributaries along the main stem or from localized debris- or ice-jams. Inundated areas shown should not be used for navigation, regulatory, permitting, or other legal purposes. Although the USGS intends to make this server available 24 hours a day, 7 days a week, timely delivery of data and products from this server through the Internet is not guaranteed. The USGS provides these maps "as-is" for a quick-reference, emergency planning tool but assumes no legal liability or responsibility resulting from the use of this information.

If this series of flood-inundation maps will be used in conjunction with National Weather Service (NWS) river forecasts, the user should be aware of additional uncertainties that may be inherent or factored into NWS forecast procedures. The NWS uses river forecast models to estimate the quantity and timing of water flowing through selected river reaches in the United States. These forecast models (1) estimate the amount of runoff generated by a precipitation event, (2) compute how the water will move downstream, and (3) predict the flow and stage (water-surface elevation) for the river at a given location (Advanced Hydrologic Prediction Service [AHPS] forecast point) throughout the forecast period (every 6 hours and 3 to 5 days out in many locations). For information on AHPS forecasts, please see: http://water. weather.gov/ahps/pcpn_and_river_forecasting.pdf.

\section{Summary}

A series of estimated flood-inundation maps was developed by the U.S. Geological Survey (USGS), in cooperation with DeKalb County, Georgia, for a 5.3-mile reach of South Fork Peachtree Creek that extends from 500 feet above the Brockett Road bridge to the Willivee Drive bridge. These maps, available at a USGS Web portal, in conjunction with the real-time stage data from the USGS streamgage at South Fork Peachtree at Casa Drive, near Clarkston, Georgia (02336152), and National Weather Service flood-stage forecasts, can help to guide the general public in taking individual safety precautions and can provide local officials with a tool to efficiently manage emergency flood operations and floodmitigation efforts.

The maps were developed using the U.S. Army Corps of Engineers HEC-RAS and HEC-GeoRAS computer programs to compute water-surface profiles and delineate estimated flood-inundation areas for selected stream stages. The maps show estimated flood-inundation areas overlain on high-resolution, georeferenced, aerial photographs of the study area for 0.5 -foot increments of stream stage between 6.0 and 12.0 feet (gage datum) at the South Fork Peachtree at Casa Drive, near Clarkston, Georgia, streamgage (02336152). 


\section{References Cited}

Bales, J.D., Wagner, C.R., Tighe, K.C., and Terziotti, Silvia, 2007, Lidar-derived flood-inundation maps for realtime flood-mapping applications, Tar River Basin, North Carolina: U.S. Geological Survey Scientific Investigations Report 2007-5032, 42 p. [Also available at http://pubs.usgs. gov/sir/2007/5032/.]

Clark, W.Z., Jr., and Zisa, A.C., 1976, Physiographic map of Georgia: Georgia Geologic Survey, scale 1:2,000,000.

Esri, [2015], ArcGIS Desktop (ver. 10.2.2): Esri, accessed April 2015 at http://www.esri.com.

Federal Emergency Management Agency, [2013], Digital flood insurance rate map: accessed July 2015 at http://www.msc.fema.gov.

Fry, J.A., Xian, George, Jin, Suming, Dewitz, J.A., Homer, C.G., Yang, Limin, Barnes, C.A., Herold, N.D., and Wickham, J.D., 2011, Completion of the 2006 National Land Cover Database for the conterminous United States: Photogrammetric Engineering \& Remote Sensing, v. 77, no. 9, p. 858-864.

Gotvald, A.J., and Knaak, A.E., 2011, Magnitude and frequency of floods for urban and small rural streams in Georgia, 2008: U.S. Geological Survey Scientific Investigations Report 2011-5042, 39 p.

Homer, C.G., Dewitz, J.A., Yang, Limin, Jin, Suming, Danielson, Patrick, Xian, George, Coulston, John, Herold, N.D., Wickham, J.D., and Megown, Kevin, 2015, Completion of the 2011 National Land Cover Database for the conterminous United States-Representing a decade of land cover change information: Photogrammetric Engineering and Remote Sensing, v. 81, no. 5, p. 345-354

Musser, J.W., 2012a, Flood-inundation maps for Peachtree Creek from the Norfolk Southern Railway Bridge to the Moores Mill Road NW Bridge, Atlanta, Georgia: U.S. Geological Survey Scientific Investigations Map 3189, 9-p. pamphlet, 50 sheets, accessed March 2012 at http://pubs.usgs.gov/sim/3189/.
Musser, J.W., 2012b, Flood-inundation maps for Suwanee Creek from the confluence of Ivy Creek to the Noblin Ridge Drive Bridge, Gwinnett County, Georgia: U.S. Geological Survey Scientific Investigations Map 3226, 8-p. pamphlet, 19 sheets. [Also available at http://pubs.usgs.gov/sim/3226/.]

Musser, J.W., 2012c, Flood-inundation maps for Sweetwater Creek from above the confluence of Powder Springs Creek to the Interstate 20 Bridge, Cobb and Douglas Counties, Georgia: U.S. Geological Survey Scientific Investigations Map 3220, 10-p. pamphlet, 21 sheets. [Also available at http://pubs.usgs.gov/sim/3220/.]

Musser, J.W., 2015, Flood-inundation maps for Big Creek from the McGinnis Ferry Road Bridge to the confluence of Hog Wallow, Alpharetta and Roswell, Georgia: U.S. Geological Survey Scientific Investigations Map 3338, 10-p. pamphlet, 19 sheets. [Also available at http://dx.doi.org/10.3133/sim3338.]

Musser, J.W., and Dyar, T.R., 2007, Two-dimensional flood-inundation model of the Flint River at Albany, Georgia: U.S. Geological Survey Scientific Investigations Report 2007-5107, 49 p., accessed March 2012 at http://pubs.usgs.gov/sir/2007/5107/.

U.S. Army Corps of Engineers, Hydrologic Engineering Center, 2010, HEC-RAS River Analysis SystemHydraulic reference manual (ver. 4.1): U.S. Army Corps of Engineers, [variously paged].

U.S. Army Corps of Engineers, Hydrologic Engineering Center, 2014, HEC-GeoRAS, GIS Tools for support of HEC-RAS using ArcGIS_-User's manual (ver. 10.2): U.S. Army Corps of Engineers, [variously paged].

U.S. Census Bureau, [2015], State and County quickfacts: U.S. Census Bureau, accessed July 2015 at http://quickfacts. census.gov/qfd/index.html.

Whitehead, M.T., and Ostheimer, C.J., 2009, Development of a flood-warning system and flood-inundation mapping for the Blanchard River in Findlay, Ohio: U.S. Geological Survey Scientific Investigations Report 2008-5234, 9 p. [Also available at http://pubs.usgs.gov/sir/2008/5234/.] 
Manuscript approved on October 1, 2015

Prepared by the USGS Science Publishing Network Edited by Rebekah J. Davis, Rolla PSC

Illustrations and layout by Caryl J. Wipperfurth, Raleigh PSC

For more information about this publication contact: Director

U.S. Geological Survey

South Atlantic Water Science Center

720 Gracern Road

Columbia, SC 29210

http://www.usgs.gov/water/southatlantic/ 


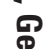

$\stackrel{10}{\circ}$

음. 